\title{
Teaching Empathy with Brecht as Prompter
}

\author{
Ellen Foyn Bruun \\ Associate Professor \\ Department of Art and Media Studies \\ Norwegian University of Science and Technology \\ NTNU Trondheim \\ Norway
}

\begin{abstract}
Empathy is a contested concept, understood in different ways. It is pertinent to explore and teach empathy today. Our ability as humans to make informed choices guided from heart and head in balance, needs to be addressed along with profound ethical issues. Re-newer of $20^{\text {th }}$ century theatre Bertolt Brecht is known for his scepticism of empathy. He encouraged audiences and actors to be rational rather than to empathise. In this article, I propose however that the theatre of Brecht, in arts education, offers useful insight into empathy as a competence engaging feeling and intellect likewise. I argue that it is possible to discover fresh aspects of empathy and acquire empathetic skills through staging Brecht's plays. The teaching practice is demonstrated with case examples from the BA Program in Drama and Theatre at The Norwegian University of Science and Technology, NTNU, Trondheim, Norway.
\end{abstract}

Keywords: Empathy, theatre, Bertolt Brecht, arts education, empathetic connection, entangled empathy, relational empathy, empathic skills.

\section{Introduction}

The study of empathy seems to have currently caught the attention of a wide range of research communities and disciplines in the social sciences, humanities, neurosciences and new technologies. It has also become a pertinent topic for studies that bridge and challenge conventional disciplines in a time in which we as humans are facing new challenges as a species that were difficult to imagine only twenty years ago. Neuroscientist Anthony Damasio's benchmark book Descartes's Mistake is an example of this trans-disciplinary legacy that challenges assumptions about biological predisposition and social construction, and has flourished since the 1990s taking a paradigmatic turn to affect and emotions (see for example Barad 2007; Clough 2008; van der Kolk 2014). Empathy, as summed up by philosopher Lori Gruen, is a many-faceted term. She suggests that, '[b]eing able to understand what another being feels, sees, and thinks, and to understand what they might need or desire, requires a fairly complex set of cognitive skills and emotional attunement' (Gruen 2015, 48). General understanding of empathy rests on our ability to understand another and the clear sense that the other is not me. Gruen states that empathy is linked to the ability of humans and nonhumans to 'differentiate between self and other' (Gruen 2015, 48). She furthermore explains that 'the empathizer does not mirror or project emotions, but is engaged in a reflective act of imagination that puts her into the object's situation and/or frame of mind, and allows her to take the perspective of the other' (Gruen 2015, 48). The idea of taking the perspective of the other distils empathy into a phenomenal embodied experience. In arts education, such as theatre, empathy therefore plays an important part as theoretical concept and as phenomena of exploration.

Bertolt Brecht encouraged the audience to take the role of analytical scientist rather than that of empathic witness. His theatre 'appeals less to feelings than to the spectators' reason' (Unwin 2016, 55). I still argue in this article that the practical theatre work prompted by Brecht, offers noteworthy insight into empathy and that it proposes pragmatic devices to stimulate empathetic awareness. First, I present the educational context and the over-arching didactical objective. I then give a short historical overview of the notion of empathy and narrow down onto Brecht's thinking in theory and practice. I demonstrate and corroborate my argument with the bachelor students' practical explorations of Brecht's plays. The BA in Drama and Theatre is offered at The Norwegian University of Science and Technology, NTNU, Trondheim, Norway. It is a practical-theoretic program that prepares graduates to bring drama and theatre skills into a range of professions, such as education, culture and social contexts. 


\section{Educational context and aims}

Bertolt Brecht (1898-1956) was an important theatre pioneer of the 20th century who is widely acknowledged into the post-dramatic era of the $21^{\text {st }}$ century. Most of his plays were written in the period between the First and Second World War. They reflect the political instability and consequences of human exploitation and violence of the times. Brecht was, in addition to being a playwright, also a dramaturge, stage director, poet, thinker and writer of theatre theory. The relationship between his theoretical and practical work is complex and the correlation between the two often ambiguous. The Brecht scholar and translator John Willett states that it is necessary to study Brecht's artistic practice rather than his theoretical writings, to understand his theories fully (Willett 1964, 168). This is also my experience. I therefore encourage students to study Brecht's theories while working practically with his plays. This happens in full production, in rehearsals and in exploratory workshops.

It seemed appropriate to revisit Brecht's plays in 2016, one year after the peak of the Syrian refugee crisis. Brecht was also a refugee, his family fleeing from Nazi Germany from 1933 until the Second World War was well over. He wrote many of his main plays in exile in the Nordic countries, the Soviet Union and the USA. After the war, he returned to the German Democratic Republic and East Berlin to form and co-run the Berliner Ensemble with his wife, Helene Weigel, until his death in 1956. The company achieved extensive international recognition as an innovative ensemble theatre and became a model for socially engaged theatre practice all over the world. Brecht's influence has also been important in the Arab speaking countries. This became clear to me when I met Syrian theatre scholar and refugee, Rafik Koushha, in Trondheim. Through our talks, we discovered a shared interest. I decided therefore that the BA theatre production for spring 2016 would be dedicated to Brecht, a playwright I had studied and worked extensively with in the past, including as a student of dramaturgy in East Berlin and later in Norway and Denmark. The collaboration with Koushha and other newly arrived refugees in the area was supported by the university policy. We established the Refugee project (Bruun, Haagensen, Søhol 2017) which was run in parallel with the students' production period from April to June. During the rehearsal period, the students contributed to the outreach audience work. This focused on newly arrived refugees in the region who were invited to pre-performance events and then as audience to the final performances. The four performances were each based on one of Brecht's plays, each lasting 35-40 minutes and with around eight students in each group. The International Rights Agency Nordiska that represents Brecht in Scandinavia gave permission to adapt Brecht's work for this purpose. The plays assigned were:

Senora Carrar's Rifles. (Brecht 1937). One Act play.

Mother Courage and her Children. (Brecht 1939). Scene 1 and 3.

The good Person of Setzuan. (Brecht 1942). Scene 3-5.

The Caucasian Chalk Circle. (Brecht 1945). Scene 12-29.

Stephen Unwin reminds us that 'Brecht sets the modern theatre artist a tough challenge' (Unwin 2016, 135). He further argues that Brecht provides us with unique inspiration once we have found the connection between his plays and our own present reality (Unwin 2016, 135). The intention of the outreach initiatives was to provide a bridge for the students between Brecht's plays and their own context, impacted by the refugee crisis. The idea of a bridge and an outward focus resonates with empathy. It resonates in particular with the notion of empathetic connection, David Krasner stating that the "connecting process enhances rather than diminishes our reflection (Krasner 2006, 262). Krasner finds support in Martha C. Nussbaum who contends that empathy involves a participatory enactment of the sufferer, but is always combined with the awareness that one is not oneself suffering' (Krasner 2006, 263). The intention of the didactical framing of the students' theatre production course and the Refugee project was to promote a thought-provoking and appealing learning environment for all parties involved, students, lecturers, partners and audience. The Norwegian reality in 2016 of having received around 30.000 Syrian refugees had an important impact of the city of Trondheim and its region. It was an opportunity to engage with agency with this social context and start building relationships and inviting new audience groups into the theatre and the university.

\section{Mapping empathy}

The study of Einfühlung in aesthetic philosophy gained ground during the $19^{\text {th }}$ century Romantic era. The Romantics defined empathy as our ability as humans to project ourselves into the soul of another person or into nature (McConachie 2016, 429). The notion of identifying and merging with the 'object of contemplation' is therefore an aspect of empathy. 
Krasner refers to the power of projecting one's personality into another being or object of art in order to understand it fully (Krasner 2009, 258). Psychologist Edward Titchener first coined empathy as an English term in 1909 (Krasner 2009, 265). Empathy can however be traced directly to the Greek Empatheia and Aristotle's concept of Pathos, the complexity and many different understandings of empathy therefore not being surprising. Bruce McConachie writes that 'the English meanings of "empathy" have never been stable' (McConachie 2016, 429). It can, even so, be said that empathy involves projecting oneself on-to or in-to something else and, through this, acquiring an understanding of the 'something else'. The intimate connection between theatre and empathy is ubiquitous, although multi-faceted. Krasner examines empathy in the theatre, focusing on audience response (Krasner 2006, 255). He concludes that empathy inspires imagination, intuition and observation in the act of comprehending another world (Krasner 2006, 256). Krasner further argues that empathy, rather than excluding those outside the boundary of oneself, is an experience that grows beyond oneself. In his terms, it 'builds outwardly' (Krasner 2006, 258). He refers to Michael Goldman who defines the performer as the 'actor-ascharacter', those observing the performer relating to them in a special way 'because they are different and more interesting than people in ordinary life' (Krasner 2006, 257). Empathy as projection arises when we, inspired by the narrative, actor or character, enter into the play world through our imagination. I expect most of us recognize the audience experience of being drawn into the performance. Krasner, however, claims that empathy is not merging with the other, because empathetic response assumes the distinction between self and other (Krasner 2009, 258). It might however, in practice be difficult and even undesirable to draw clear boundaries between self and other. Acting and making theatre allows the study of this experiential phenomenon through embodied practice. Brecht's work is particularly suitable to this study and for acquiring knowledge about empathy because he himself was so aware of the dilemmas that empathy involves.

\subsection{The limitations of empathy}

Right from the start of his career, Brecht opposed the concept of theatre as a distraction that allowed audiences to escape into fantasy and forget about the social and economic realities (McConachie 2016, 429). According to Juliet Koss $(2006,152)$, witnessing of the rise of the film industry and mass entertainment in the wake of The Great War had an important influence on Brecht and his contemporaries. The user of the arts was no longer restricted to the educated classes but extended to the uneducated masses and 'shop girls' that were allegedly easy prey to the drug of absorption and passivity (Koss 2006, 152). Another backdrop to Brecht's mistrust of empathy is the mass spectatorship of Nazi propaganda. He was critical of the kind of spectatorship that 'entailed a loss of self and over-identification with the object of attention' (Koss 2006, 153). Brecht instead wanted to develop a new kind of spectator, based on rational rather than empathic response (McConachie 2016, 429). He developed his ideas on the epic theatre in the late 1920s after studying the works of Karl Marx and already an established playwright and director in German theatre. The result was his manifesto of the epic theatre published in 1930, written whilst he worked on The Threepenny Opera and Mahagonny (Brecht 1964, 37). The opposites of epic and dramatic dates back in Western literature. An example of the epic mode is Odysseus telling his tale from a subjective and present stance, as a narrator, looking back with distance on the events. An example of the dramatic mode is Oedipus in the play by Sophocles. Oedipus experiences his situation directly in front of the audience without distance or reflective perspective. The rise of the novel in the $19^{\text {th }}$ century and Naturalism, through combining prose and documentary, had prepared the ground for the use of the epic mode as a theatrical device around the turn of the century. The view of the human condition however was, for Naturalism, universal and deterministic and the opposite of the historic-dynamical view of Brecht. In 'Notes to Mahagonny' Brecht argues for modern theatre with a shift of emphasis from dramatic to epic mode (Brecht 1964, 37). One of the main points Brecht makes is that this shift permits an outside and reflective perspective on the dramatic events on stage. He advocates a shift of emphasis, not of excluding modes. His plays examine the human condition as human made and contextual. Brecht goes against a universal and deterministic view of humankind (Brecht 1964, 37). This means that dilemmas of choice and potential change are imperative aspects in his plays.

\section{Exploring empathy with Brecht as prompter}

\subsection{First exploration: Mother Courage and her Children}

Mother Courage and her Children (Brecht 1939) illustrates how Brecht put his philosophy into play. Like a scientist, he puts the protagonist, Courage, under the microscope and studies her in different situations. 
The play is set in the Thirty Years War (1618-1648) and follows Courage who sells supplies from her wagon to the troops, to both Catholics and Protestants depending on who can pay. The harsh face of war, how it effects and breaks up family relations, is present throughout the play. The Courage family is, at the beginning, made up of the two sons who pull the wagon like strong bulls, the mother and mute daughter who sit cheerfully on the wagon with the goods. Brecht starts the first experiment: how will Courage act when she is tested as a mother and a businessperson at the same time? The scene reveals the different manipulative tactics used by the recruiters to get Eilif to sign up as a soldier, including them praising his strong body. One of the recruiters lures Courage behind the wagon to 'take a closer look at a belt buckle'. Eilif, seeing this as his opportunity for freedom from the mother, signs up while Courage gets the money for the buckle. It was a challenge to get grips with the complexity of this first scene. They first understood and played the relationship between mother and children realistically with identification. The clarity of the situation as an experiment came to the foreground after a lot of rehearsing, analysis and trying out on the floor. They were then able to take their work 'to the next level' and stage the scene appropriately with sharpened situations. For example, they turned the family of four, when presenting themselves to the recruiters, into a glamorous show using the visual and musical effects of a travelling circus and fair grounds. Lights flashed in all colours, the three children showing off with cartwheels and juggling. The recruiter shows fear and appears to believe Courage when she, like a cliché of a Gypsy queen, tells his fortune and predicts his death. The audience does not know for sure whether he is afraid or is playing along to get her behind the wagon later. The family show continues, the strong united family presenting the attitude of 'we are invincible and un-vulnerable'. Courage in the same sequence predicts the death of her children as part of the act. This acts as entertainment for the recruiters and as a warning to the children. It also for-shadows the play itself. At the end, Courage has lost her three children. She continues alone, following the war wherever it goes. The multi-layered irony from Brecht's hand is subtle, yet brutal. Once the students were able to read the play with a more clinical lens and understand it as a collective 'research' experiment rather than as a representation of reality, the principle of contradiction supported and stimulated their creativity.

\subsection{Brecht's epic theatre in theory}

The idea of theatre as an experiment in unfolding a social hypothesis, as derived from 'Notes to Mahagonny' (Brecht 1964, 37), penetrates Brecht's plays. The dialectical approach embeds the possibility of a counterexperiment and as a result makes change possible. The deterministic worldview of Naturalism was, in the time of Brecht, replaced with the utopia of Marxism and the optimistic belief in progress and a better world of equal opportunities and equal distribution of wealth and resources. The global challenges we are dealing with today in the $21^{\text {st }}$ century are sadly proof of shortcomings of manmade worldviews and choice making on behalf of humans and nonhumans. The legacy of Brecht and many of his generation may be understood as warning and premonition of today's global affairs. Brecht was a model researcher in practice through his persistence in revealing contradictions and encouraging what he called 'complex seeing' (Unwin 2016, 67). On stage, dynamic contradictions can become visible and exposed as different angles of an argument. In practice, Brecht developed techniques that equally stimulated the intellect of theatre artists and audience, the purpose being to enable them to see new sides of an argument and so broaden their perspectives. Brecht wanted to reveal contradictions rather than the smoothing over of contradictions and the creation of false harmony of the bourgeois theatre. His epic theatre demonstrates a vision of a new spectator, one that is awakened to action and social engagement. The new spectator is, in brief, able to enjoy the pleasure of learning while being entertained, the comprehensive pleasure of sophisticated entertainment and education seeping the complete works of Brecht and his legacy to this day. Emotional immersion in what was presented on stage was, for Brecht, counter-productive with risk of escapism and passivity. Unwin sums this up by saying that the "techniques of the "epic theatre", the "alienation effect" and "gestus" all bring out the contradictions inherent in the work, and in the world: complex seeing is fundamental" (Unwin 2016, 68). In 'The short Organon for the theatre' Brecht writes that '[a] representation that alienates is one which allows us to recognize its subject, but at the same time makes it seem unfamiliar' (Brecht 1964, 192).

\subsection{Second exploration: The Caucasian Chalk Circle}

For the student group working with The Caucasian Chalk Circle the exploration of 'gestus' became particularly significant. 'Gestus' refers to acting in epic theatre and to the role of the actor as storyteller and as demonstrator of human behaviour. Unwin sums this up by saying that '[i]n essence, "gestus" means presenting action with quotation marks around it (a direct extension of the "alienation effect") (Unwin 2016, 64). One method that can help actors achieve this is referring to the characters in the third person and describing the situation as a story. 
These are familiar tools in prose and storytelling, but were novel to introduce in conventional Western acting techniques at the time of Brecht. The Brechtian logic of 'gestus' in the previous example from Courage would lead to the actress expressing something like, 'this is how a woman looks like when she realises she has lost her son because of her own greed'. The purpose of 'gestus' is to explore the social circumstances of the character and through this raise the analysis above the private psychological sphere and enable a wider and social perspective to emerge. The main character in The Caucasian Chalk Circle, Grusha, is on a dangerous journey as she flees a rebellion that has destabilized her country. Grusha is a servant girl who worked for the dethroned governor. During the attack on the palace, she picks up and flees with the governor's baby son in the chaos. From this point on, the dilemma is the contradiction of her own survival contra the survival of the child, the heir to the throne. Brecht was apparently critical of Grusha's empathetic urge and 'maternal instinct to save the child. A closer look at the text however reveals that the child is wrapped in a valuable cloak. On her journey, Grusha meets other refugees, a hotel owner, local peasants, soldiers and family. They all represent preconceived social attitudes that overshadow their individuality. In one of the early scenes, Grusha arrives at a guesthouse with the child, at the same time as two upper class women. The audience has just seen her in the previous scene haggling for milk from a peasant woman, allegedly for the child. The focus on money revealed in the example from Courage also penetrates the dialogue between the innkeeper and the three women. Once the deal for accommodation is agreed, the women enter the room they are to share. There are no beds in the room so Grusha begins to organize what is available to make some kind of bed while the two other women talk about the uncertain times and that servants are not to be trusted at any cost. They become aware of Grusha who is organising the room for the night. She is caught red-handed as a servant. The confrontation that follows demonstrates all conceivable preconceptions of 'poor people' as swindlers, murderers and thieves. The women want to call the police. There are however no police in the chaotic times of rebellion. Grusha gets away and her journey continues.

When the students had explored the scene through empathy with Grusha they found that it resonated with the refugee context, in the past and at present. They found a focus that enabled them to make the final choices for the performance. The social 'gestus' of all the characters came to the foreground once they had understood the theoretical concept in practice. It was not about playing stereotypes, but about being thorough and precise in each situation, exploring the power dynamics and turning points through amplification and systematic examination of the contradictions on the floor. The Chalk Circle, the students' title of the performance, included many characters. All, except the actor who played Grusha, played two to three characters. This suited the play well, as it is a long journey, throughout which Grusha continuously faces new obstacles. According to the students, having to create and embody different and often opposite characters also added important learning value (Production report, The Chalk Circle 2016). The notion of 'gestus' and the exploration of social habits and body language contributed to their learning process of empathy as a skill that combines heart and head, and flexibility of perspectives. So did the idea of theatre as storytelling and the awareness of acting itself as a container of the paradox of performer and character. Learning and practicing empathetic ability through theatre therefore works as a holistic experience and activity that trains the competency to juggle identification and distancing effortlessly and intuitively.

Brecht as result of making drama more like prose and storytelling introduced simple acting methodology, namely the advice to actors to shift perspective between the first and third person perspective during rehearsal. This enhances empathic competence and enhances flexibility of thought and imagination. Being able to contain the binary opposites of subject and object is, furthermore, potent as it underpins the relational inter-dependence in all social interactions and living systems, not just in performance. Gruen, some generations after Brecht and from the field of current moral philosophy, advocates that we are not only in relationships but we become what we are in those relationships. She uses feminist philosopher Karen Barad's concept of intra-actions when describing the self that becomes what it is because two or more separate things come into contact (Gruen 2015, 64). Gruen launched her version of empathy through coining the term, entangled empathy. Entangled empathy, according to her, requires the ability to shift between first and third-person perspectives. This is in line with Brecht's principal dialectical approach. It also challenges the static idea of exclusive separation between the subject and the 'object'/other subject. Empathy, for Gruen, involves stimulating both affective and cognitive faculties and considering similarities and differences between the empathizer and the one with whom it is empathized. The shift between perspectives makes it possible to think relationally, so avoiding being lulled into just one perspective (Gruen 2015, 66). Theatre practice in consequence offers a unique pragmatic learning tool to teach and acquire empathetic skills. 


\subsection{The survival of empathy}

The students' productions were launched as a Brecht festival, all four performed four times in four days as the BRECHTIVAL. The four shows could be seen consecutively as a four-hour marathon or the audience could pick which ones they wanted to see. The Refugee project was developed in parallel with the rehearsal period. The first stage of the project was establishing and expanding the network with the help of Rafik Koushha and others in public bodies who worked with newly arrived refugees and immigrants. We then arranged a number of events that integrated lectures, drama workshops, pizza and social exchange with those in the network. A main participant group in these events and later in the audience was a group of adolescents who were in the process of being integrated into the Norwegian educational system. Some were minors others around the same age as the students, early 20s. One of the groups reflects as follows in their report:

Thursday 12 May we arranged a social evening with drama games and improvisation. This was incredibly inspiring for us all. We discovered that we had much more in common than we first thought. Young people are young people and this became evident. It is good to see that these young people have a group to relate to. It is, perhaps, difficult to bond with networks outside of this. Hopefully, they experience it as inclusive and heartfelt to meet young Norwegians at the university in this setting. (Production report Setzuan 2016, 24, author's translation)

Once the relationship was established, the focus developed on sharing knowledge about the legacy of Brecht in different parts of the world, in particular in the Arab speaking cultures. People in Norway generally know little about theatre in Syria. It was therefore instructive to learn about a prospering tradition in Syria in which Brecht and socially engaged theatre has played an important role since the 1950s. It was also important to present the relevance of Brecht's plays as parables, often set in distant landscapes 'far away', such as the Caucasus, Setzuan and the Thirty Years War. Brecht's use of poetic distance provides an imaginal space for reflection and feeling alike. As I have revealed, this can create the connection to our own times and context.

\subsection{Third exploration: Senora Carrar's Rifles}

Senora Carrar's Rifles from 1937 is closer to a conventional drama and to Brecht's own time. It was first produced in Paris, with Helene Weigel as Carrar, when the Spanish Civil War (1936-1939) was at its peak (Willett 1964, 44). The Norwegian students associated the play with any kind of civil war and its consequences for ordinary people, their survival and choices. The students' focal point was the notion of neutrality as the characters are ultimately forced to take sides even where resisting and refusing to choose sides as long as possible. Brecht produced the play for his fellow international writers in Paris 1937. At the same time, volunteers from all over the world we joining the international brigade to fight against Spanish fascism. It is almost as if the play reflects Brecht's own dilemma and that of many of his contemporaries. The play takes place an evening in a fisherman's while the last bread Carrar has flour for bakes in the oven. She, much like Courage, does not want to lose her sons to the war. At the end of the play, however, her eldest son is carried in dead. She then turns to take out the rifles she has hidden for her late husband and leave for the front with a loaf of fresh bread under her arm. It comes as quite a surprise that Carrar chooses violence in the end. The students experimented in rehearsals with making the character's devlopment plausible. Then it became clear that the dramatic fiction was disrupted by Brecht himself. In each scene, Carrar is confronted with new arguments by the characters that come and go. This understanding encouraged the students to underpin that the play was staged through their perspective, a group of undergraduate students in Norway in 2016. Inspired by Brecht himself they introduced a distancing, epic layer of performing performers that they interweaved into the narrative of Carrar.

\subsection{Moving the audience to action and caring}

I have demonstrated that Brecht cautioned against empathetic manipulation and therefore invented devices to trigger the audience's intellectual capacities. What he cautioned against was the subjugation and objectification of the audience. He did not want them to become passive and led astray by passions (Krasner 2006, 463). Brecht wrote and produced theatre that instead should stimulate the intelligence of the audience and set them in motion to make changes in their own social reality. The idea of the autonomous spectator is equally valid today in an era where concepts such as relational aesthetics (Bourriaud 2002) and the emancipated spectator (Rancière 2009) have become mainstream. Arts practice tends in all fields, including theatre and its applications in education, activism and therapy, to be regarded as a relational and social-dynamic exchange. This resonates with Brechtian aesthetics that holds that the spectator and the actor are at the mercy of one another. 
I have shown that Brecht's epic theatre deals with the complex triangular relationship of spectator, actor and performance. Brecht writes with admiration in his notorious piece on the 'Alienation Effects in Chinese Action' about the actor's craft and about how the (Chinese) actor manages to convey the two-folded expression of technique and grace (Brecht 1964, 92). He writes that the 'artist has been using his countenance as a blank sheet, to be inscribed by the gest of the body' (Brecht 1964, 92). He continues to draw from this his own propositions of distancing effects and criticises the Western acting tradition of aiming at 'the closest proximity to the events and character he has to portray' (Brecht 1964, 93). An important point Brecht makes is that the actor's 'self-alienation and ability to self-observe enables performer and spectator to be aware of and stay present in the shared reality of the theatrical social exchange' (Brecht 1964, 93). Brecht shifts emphasis from empathetic awareness with the fictional character to empathetic awareness with the performer. By this, he underpins theatre and performance as a social event that takes place in the present. He writes that,

[t]the performer's self-observation, an artful and artistic act of self-alienation, stopped the spectator from losing himself in the character completely, i.e. to the point of giving up his own identity, and lent a splendid remoteness to the events. Yet the spectator's empathy was not entirely rejected. The audience identifies itself with the actor as being an observer, and accordingly develops his attitude of observing and looking on. (Brecht 1964, 93)

\subsection{Fourth exploration: The Good Person from Setzuan}

Krasner introduces the term 'empathetic connection' to better understand how Brecht orchestrates the encounter between spectators and performers (Krasner 2006, 262). Empathetic response is, for Krasner and others (Krasner 2006; Gruen 2015; Nussbaum 2001), a prerequisite for caring and compassion. This corresponds with Brecht's technique, as it raises the kind of empathy to that Krasner refers to as 'the reaching out' process 'enabling us to walk in someone else's shoes without sacrificing critical reflection' (Krasenr 2006, 262). Empathetic connection enhances understanding rather than diminishes it. It furthermore does not necessarily mean loss of identity, self or judgement (Krasner 2006, 262). Krasner also asks how the audience could be moved to act if they failed to care about the actions on stage (Krasner 2009, 262). The aspect of caring was pertinent in the students' work. This was supported by the Refugee project, but not exclusively. In The Good Person from Setzuan, the dilemmas of the protagonist, Shen Te, are presented with such contradictions that they appear heart breaking. How can she be a good person and help others when she herself is brutally exploited? She invents her own bad cousin who has no ethical scruples, so allowing her to face circumstances better. The sequence the students worked with was from the first half of the play until the marriage of Shen Te and Sun. Sun is a poor and miserable pilot who Shen Te first meets under the tree from which he is trying to hang himself. Shen Te talks him out of it and falls in love with him, and he maybe falls in love with her too. However, helped by his mother, Sun uses Shen Te to get hold of her money. The play offers quite a complex variety of feeling responses ranging from romantic identification to indignation and resentment. The students' performance ended with Shen Te's monologue rejecting the bad cousin, indulging for one moment in the fantasy of romantic love. She says,

I want to go with my lover.

I do not want to know what it costs.

I do not want to know if it is sensible.

I do not want to know if he loves me.

I want to go with my lover. (Brecht 1945, scene 5)

The scene came across as poetic and ironic at the same time. An empathetic connection was established with both characters from the moment they first appear, based on the communal understanding between the actors and the spectators of the limitations of the characters. This seemed to create both ironic distance and caring. It resonates with the qualities of Brechtian acting, listed by Unwin, corroborating the notion of complex seeing and contradiction. The first point on this list is Intelligent (Unwin 2014, 92). The example above invited a multilayered response from actors and audience alike that engage with intelligence in a broad sense. Unwin also includes Ironic on the list of Brechtian acting qualities (Unwin 2014, 92). He elaborates that ironic relates to 'an acute awareness of dramatic irony - where the audience knows more than the character' (Unwin 2014, 92). He could have been more specific and added that the audience and actor know more than the character. This, as I have demonstrated, would be more accurate and in the spirit of Brecht. 
A third quality on Unwin's Brechtian acting list $(2014,93)$ is Elegant, which resonates with Brecht's assertion that the actor's craft and artistry 'helps us see that the events being presented can be changed' (Unwin 2014, 93).

\subsection{Relational empathy}

The term relational empathy, as proposed by Maureen O'Hara (1997), seems useful in this context. O'Hara proposes empathy as a state of consciousness within a socio-centric frame of reference and as 'a way through which relationships as entities, including groups, and communities can themselves become aware of themselves as wholes. Often this is accomplished through myth, ritual and other holistic forms of knowing' (O'Hara 1997, 14). The context of the BRECHTIVAL and the Refugee project, only one year after the migration crisis in 2015, led to a special awareness during the performances. Several members of the newly arrived refugee community came to see the performances, this time mixed with the dominant audience of ethnic Norwegians. The Chalk Circle, for example, presented scenes in which relational empathetic awareness was compelling. Grusha becomes little by little attached to the governor's child after leaving the inn on her journey in the Northern Mountains. In one scene, she has to cross a mountain pass over a fragile bridge with the revolution soldiers pursuing the child right behind her. She needs to leave the child behind to be sure that the bridge will carry her weight. The students amplified this dramatic moment by doubling the child-doll with a child-performer who physicalized in movement the dilemma of choice, including the feeling of compassion for Grusha and the helpless child. This example distils other moments in the performances, where the diversity of the audience contributed to an extra layer of complex understanding. The students appreciated the contact with the young refugees, one group writing that, '[w]e produce plays that are relevant to today and that can be related to themes in which these adolescents can recognise their own realities' (Student production Setzuan, 24). The Chalk Circle group conveyed, by drawing attention to the artistry and beauty of the moment that Grusha finds her strength from bonding with the child. She chooses to take the child with her over the fragile bridge, represented on stage by real stones that the child-performer presents one by one in front of Grusha. She balances from stone to stone 'over the bridge' with the child-doll in her arms and arrives safely in the other side.

\section{Conclusion}

I have demonstrated in this article how using Brecht as prompter provided a scaffolding for teaching empathy. The BA theatre production course invited the students to address empathy and engage with empathy through symbolic distance. Brecht's insistence on theatre as being a critical, analytical tool is in line with educational devices that, I believe, are urgently needed in arts education globally at present. Addressing and exploring arts education and education in general, and how empathy plays and may play a role, is part of this endeavour. I have argued that Brecht's work is of great value to us today due to the empathetic connection and relational model of shared curiosity and intimacy between spectator and performer. The Norwegian BA students discovered the relevance of Brecht's legacy in the present multi-cultural context of Norway. The exploration of empathy with Brecht's plays and theories as platform resulted in new insights and perspectives on the notion of empathy. Most importantly, the revelation of empathy as a skill that does not exclude analysis, knowledge and reflection. On the contrary, the learning process demonstrated that the distance and boundary between the empathizer and the 'object of contemplation' is a prerequisite for empathetic awareness and connection. The learning outcome further posits that empathy serves as a device for Brecht to stimulate complex meaning making and social engagement. The rejection of empathy when used to manipulate and pacify audiences into escapism and denial of reality is just as appropriate today as when Brecht lived and raised his scepticism of this aspect of empathy. It seems as important as ever in the history of humankind to educate and create knowledge that stimulates critical and caring actions and communities. Brecht's critique of mass manipulation through art and culture is a persuasive reminder today of the ethical responsibilities of any artist, arts teacher and cultural agent. It is no surprise that empathy and ethics are so intimately joined. For Gruen, '[e]mpathy is a particular type of attention, what I think of as a kind moral perception' (Gruen 2015, 39). She continues by writing that 'moral perception is not the same as ordinary sense perception, that the latter doesn't often require reflection and correction, whereas moral perception does'. This is in line with Brecht's philosophical foundation and ethical values of a clear intention to change society and human beings, based on the belief of a better world. Brecht's trust in the ability of spectators and actors to understand their communal reality in order to act accordingly fosters hope. He is however ruthless when it comes to the standards of entertainment as no boring performance would engage the audience. To sum up, Brecht advocates theatre as a complex intellectual activity with empathy as a condition for critical inquiry rather than as an obstacle. 


\section{References}

Barad, K. (2007). Meeting the Universe Halfway: Quantum Physics and the Entanglement of Matter and Meaning. Durham: Duke University Press.

Bourriaud, N. (2002). Relational Aesthetics. Translated by Simon Pleasance \& Fronza Woods with the participation of Mathieu Copeland. Dijon: Presses du reel.

Brecht, B. (1937). Fru Carrars gevar. (Senora Carrar's Rifles).

Brecht, B. (1939). Mor Courage og barna hennes. (Mother Courage and her Children).

Brecht, B. (1942). Det gode mennesket fra Sezuan. (The Good Person from Setzuan).

Brecht, B. (1945). Den Kaukasiske Krittsirkelen. (The Caucasian Chalk Circle).

Brecht, B. (1964). Brecht on Theatre - the Development of an Aesthetic, translation and notes by John Willett. London: Methuen \& Co Ltd.

Bruun, E. F. Haagensen, C. \& Søhol, C. (2017). Å bygge publikumsbroer (Building Audience Bridges). DramaNordic Journal for Drama Education. 1, 2017: 44-49.

Clough, P. T. (2008). The Affective Turn: Political Economy, Biomedia and Bodies. Theory Culture Society, $25: 1,1-22$.

Damasio, A. (1994). Descartes' Error: Emotion, Reason, and the Human Brain. New York: G. P. Putman's.

Gruen, L. (2015). Entangled Empathy: An Alternative Ethic for Our Relationships with Animals. New York: Lantern Books.

Koss, J. (2006). On the Limits of Empathy. The Art Bulletin, 01 March 2006, Vol. 88(1), 139-157.

Krasner, D. (2009). Empathy and Theatre. In Krasner, D. \& Salz, D. Z. (Eds.) Staging Philosophy: Intersections of theatre, performance, and philosophy. The University of Michigan Press.

McConachie, B. (2016). CASE STUDY: Brecht and the science of empathy. In McConachie, B., Nellhaus, T., Sorgerfrei, C. F., Underiner, T. Theatre Histories: An Introduction. E-book. Routledge.

Nussbaum, M. C. (2001). The Intelligence of Emotions. New York: Cambridge University Press.

O'Hara, M. (1997). Relational Empathy: From Egocentrism to Postmodern Contextualism. In Bohardt, A. \& Greenberg, L. (Eds.) Empathy and psychotherapy: New directions in theory, research and practice. Washington, D.C.: American Psychological Association.

Rancière, J. (2009). The Emancipated Spectator. Translated by Gregory Elliot. London: Verso Books.

Student report Chalk Circle. 2016. DRA1003: Theatre production. Trondheim: NTNU.

Student report Setzuan. 2016. DRA1003: Theatre production. Trondheim: NTNU.

Unwin, S. (2014). The Complete Brecht Toolkit. London: Nick Hern Books.

van der Kolk, B. (2015). The Body Keeps the Score: Brain, Mind, and Body in the Healing of Trauma. New York: Penguin books (paperback).

Willett, J. (1964). The Theatre of Bertolt Brecht-A Study from Eight Aspects. London: Methuen \& Co Ltd. 